\title{
Integrating ecological engineering and ecological intensification from management practices to ecosystem services into a generic framework: a review
}

\author{
Freddy Rey $^{1,2} \cdot$ Lauric Cécillon ${ }^{1,2}$. Thomas Cordonnier ${ }^{1,2} \cdot$ Renaud Jaunatre $^{1,2}$. \\ Grégory Loucougaray ${ }^{1,2}$
}

Accepted: 1 June 2015 /Published online: 1 July 2015

(C) INRA and Springer-Verlag France 2015

\begin{abstract}
There are many management approaches proposed to link practices and ecosystem services. Their common aim is to improve the levels of specific ecosystem services by driving key ecosystem functions. However, an operational common grid of analysis is needed. Among these approaches, scientists have recently put forward ecological engineering and ecological intensification which provide relevant examples for building and testing a common grid. Here, we propose to integrate ecological engineering and ecological intensification into a generic framework from management practices to ecosystem services. The novelty of this framework is to consider management practices as gradients of inputs to ecosystems. Specifically, management actions are defined according to the type and level of inputs, characterized along a gradient from endogenous to exogenous inputs, and from biological to artificial inputs. Our framework highlights the importance of the interactions between management practices and natural capital properties. These interactions determine the ecosystem functions that will sustain target ecosystem services. We then show how ecological engineering and ecological intensification can be distinguished and unified within our framework. To illustrate this, we use four ecological engineering and ecological intensification case studies representing different types and levels of inputs. Our proposed framework should thus help (1) researchers to make improved assessments of the links between practices, ecosystem structure and functions, and ultimately services, and to foster improved meta-, cost-
\end{abstract}

Freddy Rey

Freddy.Rey@irstea.fr

1 Irstea, UR EMGR, 2 rue de la Papeterie, BP 76, 38402 Saint-Martin-d'Hères, France

2 Université Grenoble Alpes, 38402 Grenoble, France benefit- and life-cycle analyses and evaluations of ecosystem management approaches; (2) project designers by improving the adequacy of their action to the specified target; and (3) managers to establish the specifications of the ecosystem management adapted to their objective.

Keywords Ecosystem functions - Ecosystem management approaches $\cdot$ Inputs $\cdot$ Land use $\cdot$ Natural capital

Contents

1. Introduction

2. A generic framework for ecosystem managementfrom practices to ecosystem services

3. Integrating ecological engineering and ecological intensification into the generic framework

4. Case studies regarding the framework for ecosystem management

5. Conclusion

6. Acknowledgments

7. References

\section{Introduction}

Ecosystem services are now recognized as a major component linking society and ecosystems and one of the key global environmental sustainability challenges for the twenty-first century. According to Costanza et al. (1997), they are defined as the benefits derived by human populations, directly or indirectly, from ecosystem functions, which correspond to the processes that operate within an ecosystem (Wallace 2007). Ecosystem services and functions depend on the natural capital through the structure of communities and the flow of 
material and energy within and between ecosystems (Costanza et al. 1997). Natural capital refers here to the structure and composition of ecosystems and more precisely to a stock of natural components that yields a flow of goods and services (Costanza and Daly 1992). It can present inherent (i.e. cannot be modified) and manageable properties (Dominati et al. 2010). While there has been substantial progress in characterizing, quantifying and in some cases evaluating certain ecosystem services, their actual incorporation into governmental and private sector policies is still in its early stages (Wong et al. 2014). Great efforts have been made to improve the evaluation of ecosystem services in different ecological contexts and for different practices in managed ecosystems (de Groot et al. 2010). Their sustainable provision to society is the main target of different ecosystem management approaches.

Such approaches linking practices and services are manifold (Gregory and Ingram 2000; Lata et al. 2011; Barot et al. 2012; Stokes et al. 2012). Emerging from various disciplines such as conservation ecology, restoration ecology or agroecology, the approaches aim to improve levels of specific ecosystem services through driving key ecosystem functions (Kremen and Miles 2012; Tixier et al. 2013). Some of these approaches have sought to promote management based on ecosystem intrinsic ecological processes in order to limit costly external inputs and negative ecological effects, as well as to improve ecosystem sustainability. Many recent studies have dealt with the potential effects of ecosystem management on ecosystem goods and services. They usually focus on three main topics: the effect of specific practices on the provision of one or several ecosystem services (Snapp et al. 2010; Schwenk et al. 2012); the interaction, trade-offs and synergies between ecosystem services, possibly under different management scenarios (Bennett et al. 2009; Duncker et al. 2012; Briner et al. 2013; Cavender-Bares et al. 2015); and how biological regulation may help drive ecosystem services (Bommarco et al. 2013). For instance, Lafond et al. (2015) showed that forest management practices inspired from natural ecosystem dynamics (i.e. retention of dead wood and creation of gaps) could sustain wood production while better preserving biodiversity.

Among the existing ecosystem management approaches, ecological engineering and ecological intensification have proved useful for practitioners and researchers (e.g. Gregory et al. 2002; Gosselin 2008; Doré et al. 2011; Lata et al. 2011; Barot et al. 2012; Mitsch 2012; Stokes et al. 2012; Griffon 2013) and are increasingly the subject of scientific papers. Mitsch and Jørgensen $(1989,2004)$ defined ecological engineering as "the design of sustainable systems, consistent with ecological principles, which integrates human society with its natural environment for the benefit of both". More recently, Rey et al. (2014) viewed ecological engineering as "actions using and/or acting for nature". It brings together all management strategies, tools and techniques for environmental intervention, as a product of the translation of the results of ecological research applied to the field. The defined strategies are designed to mimic or to adapt the natural functioning of ecosystems to reach a target ecosystem, within an overall goal of sustainable development and with minimal and preferably biological and/or endogenous inputs. Two representative examples are the implementation of bioengineering structures made of willow cuttings that can be used to trap significant quantities of sediment and efficiently restore eroded marly gullies in a Mediterranean mountain climate (Rey and Burylo 2014; Fig. 1) and the use of native plants to reduce excessive nutrients and trace element in contaminated sewage sludge (Suchkova et al. 2014).

Ecological intensification consists of managing serviceproviding organisms or using biological regulation in agroecosystems to maintain a high level of food production (the target ecosystem service) as well as to ensure synergies with other ecosystem services (Doré et al. 2011; Bommarco et al. 2013). It is founded upon four main principles that are directly related to management practices, ecosystem functions and ecosystem services: (1) maintaining a high level of production to cope with the increasing demand in agroecosystem products (e.g. Valentine et al. 2012); (2) limiting the negative ecological impact of intensification practices (e.g. Cassman 1999); (3) increasing the use of ecological processes for production (i.e. reducing mechanical and chemical inputs); (4) taking into account the provision of other ecosystem services. A typical example of ecological intensification in agroecosystems consists in enhancing forage production by using more diverse sowing mixtures in grasslands, notably by optimizing the ratio between grasses and legumes that stimulates the acquisition of nitrogen through symbiotic and non-symbiotic sources (Nyfeler et al. 2011; Fig. 1). Although ecological intensification has been discussed until now with regard to agriculture, it can also be applied to other managed ecosystems facing comparable challenges (e.g. production forests).

The development of ecological engineering and ecological intensification exemplifies the tendency, for several decades, to adapt management practices in a more sustainable way (Pretty 2008; Barot et al. 2012), for instance by limiting costly external inputs (i.e. fertilizers, intensive soil preparation) and negative ecological impacts (i.e. soil compaction, nutrient leaching, loss of bioturbators). Despite some differences in their historical backgrounds and objectives, both approaches share a number of conceptual pillars and objectives, such as maintaining or promoting a target ecosystem service through managing ecosystem structure and composition with potential positive secondary effects on other ecosystem services. Despite great efforts to improve the assessment of the efficiency of various ecosystem management approaches such as ecological engineering and ecological intensification on target 
Fig. 1 Examples of ecological engineering and ecological intensification approaches. a In mountain forests, ecological intensification seeks to improve both wood production and biodiversity using mixed stands. $\mathbf{b}, \mathbf{d}$ In the mountain grasslands of the Vercors massif in France, farmers seek to maintain or to improve forage production while enhancing other ecosystem services, such as honey production potential, or the aesthetic quality of their grasslands, in order to meet both agronomical and environmental objectives that can be achieved by using an ecological intensification approach. $\mathbf{c}$ In the southern French Alps, massive areas of bare eroded soils trigger sediment transportation that is detrimental to aquatic fauna, people through inundation and hydroelectricity dams through their silting. The implementation of ecological engineering structures made of wooden sills, brush layers and brush mats leads to sediment trapping based on plant growth
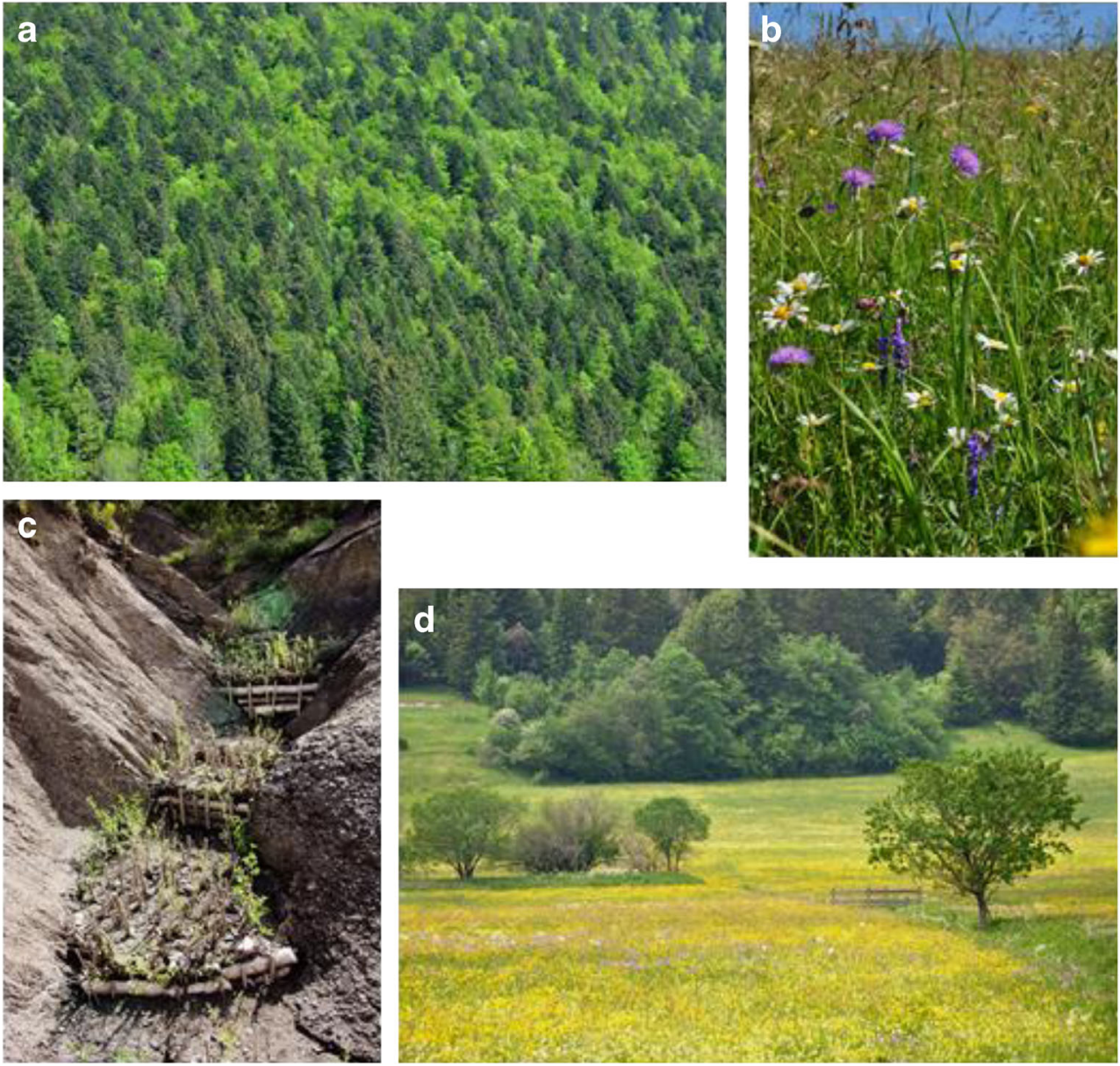

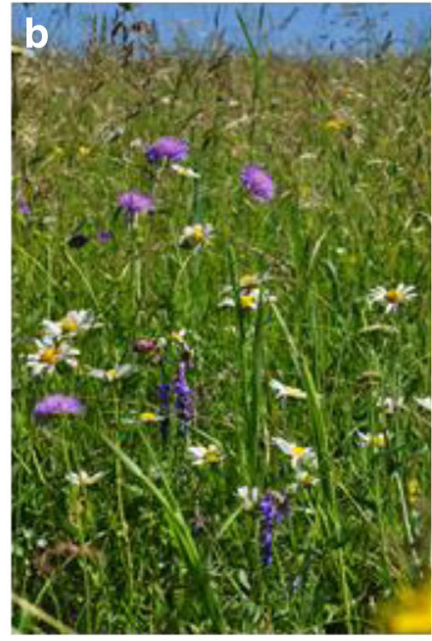
20.0 ecosystem services, knowledge of responses of ecosystem functions to management, as well as of the links between ecosystem functions and services in this wide variety of applications, is still lacking (Barot et al. 2012; Stokes et al. 2014; Wong et al. 2014). This situation calls for a common grid of analysis to promote the application of ecosystem management approaches, including ecological engineering and ecological intensification.

To achieve this goal, we suggest integrating these two approaches into a generic framework, from management practices to ecosystem services. Connections between practices, natural capital, ecosystem functions and ecosystem services are identified. The main novelty of our approach is to consider management practices as gradients of inputs, viewed as products or actions and based on their type and level: endogenous/ exogenous and biological/artificial. We then show how ecological engineering and ecological intensification can be unified and distinguished within our framework. Finally, we apply our framework to four ecological engineering and ecological intensification case studies selected from the literature and representing different types and levels of inputs. We describe its potential uses for project designers, managers and researchers involved in ecological engineering, ecological intensification and other ecosystem management approaches.

\section{A generic framework for ecosystem management - from practices to ecosystem services}

As ecosystem services and functions depend on natural capital, which itself depends largely on management practices, it is crucial to identify the interactions between the different elements of this cascading scheme. As ecosystem deliveries rely on ecosystem functions in space and time (Potschin and Haines-Young 2011), it is also necessary to keep a dynamic perspective of all these interactions. Therefore, to make a comprehensive representation of the relationships between management practices and the provision of ecosystem services, integrating natural capital and ecosystem functions, we propose the generic framework in Fig. 2. Our framework focuses on how the characteristics of management practices, based on the type and level of their inputs, can influence the dynamic relationships between natural capital (i.e. the structure and composition of ecosystems) and ecosystem functions 


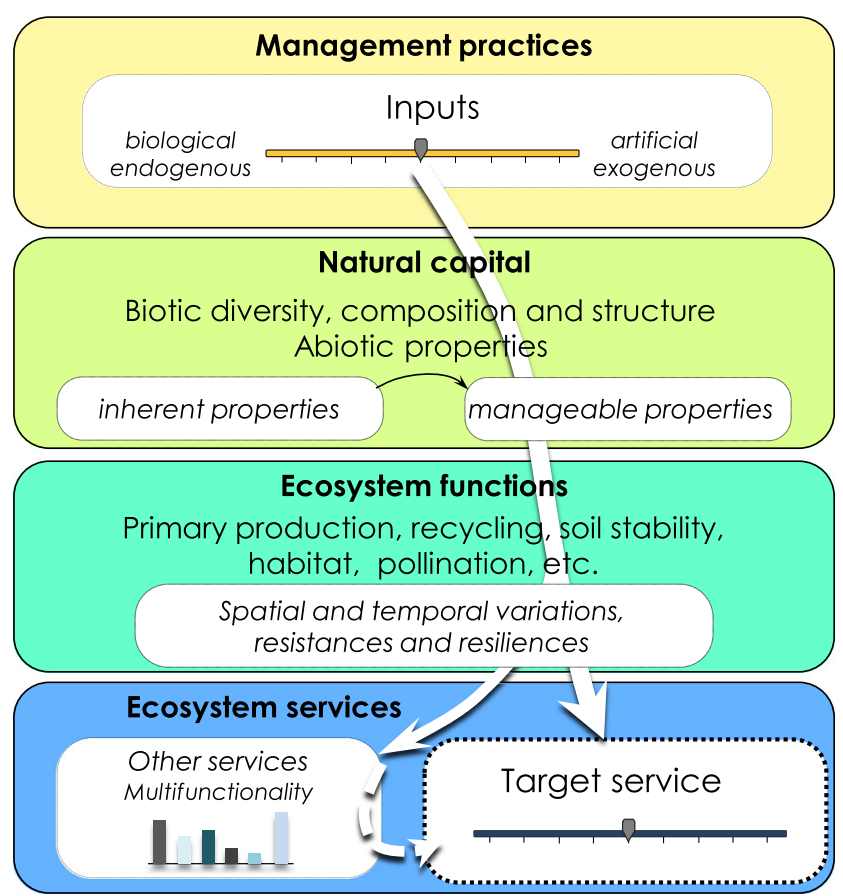

Fig. 2 Generic framework specifying the connections between management practices, natural capital, ecosystem functions and ecosystems services. The framework relies on four boxes dealing with: (1) the characterization of management practices based on the type and level of their inputs (endogenous/exogenous, artificial/biological); (2) natural capital referring to the structure and composition of ecosystems; (3) ecosystem functions integrated in space and time; (4) target ecosystem services and related trade-off with other services. The full arrow represents the cascading relationships from management to both target ecosystem services and other services. The dashed arrow represents the potential interaction between target services and other services. For the sake of clarity, potential links between each box are not represented

and how they can target ecosystem services delivery and related trade-off or synergies with other services through cascading effects. This framework is based on three different levels of interaction from management practices to ecosystem services. Although the importance of each of these interactions has already been widely established in the literature, a holistic approach that includes all of these interactions in an operational context for ecosystem management has rarely been tackled.

The first level of interaction refers to the direct and/or indirect impact of management practices on natural capital. It is interesting to note that natural capital stocks have both nonmodifiable properties and properties that respond to land management practices, termed "inherent" and "manageable", respectively, by Dominati et al. (2010). Different management practices may have contrasting effects on manageable properties such as nutrient stocks, biophysical environmental conditions and/or the composition and structure of communities within a given ecosystem (Parfitt et al. 2010; Teague et al. 2011). Across many ecosystems, from grasslands to forests, numerous studies have demonstrated the importance of management practices on components of natural capital such as nutrient availability (see for example Guo and Gifford 2002; Hungate et al. 2007; Jandl et al. 2007); microbial, plant and animal species richness and composition (Lagomarsino et al. 2009; Sebastia et al. 2011; Andrey et al. 2014); functional diversity and structure (Quétier et al. 2007; Duru et al. 2014; Van Meerbeek et al. 2014) as well as spatial and temporal patterns of nutrients (Serrano et al. 2014) and of plant and animal traits (Deléglise et al. 2011; Wickings and Grandy 2013; Molina et al. 2014).

The second level of interaction deals with the influence of natural capital on ecosystem functions. The effects of directly manageable characteristics of natural capital are well documented, such as nutrient availability and other abiotic soil properties that are usually managed in agrosystems and drive many ecosystem functions, such as biomass production, nutrient cycling or decomposition (e.g. Fridley 2002). More recently, efforts have been made to assess the importance of composition and structure of managed ecosystems on various ecosystem functions (Schwartz et al. 2000; Laliberté and Tylianakis 2012), with particular focus on the role of species and functional trait diversity. For example, soil bacterial and fungal biodiversity (Morris and Boerner 1998; Köhl et al. 2014; Wagg et al. 2014), patterns of species composition (Rossignol et al. 2006; Malcolm et al. 2014), species diversity (Balvanera et al. 2006; Kirwan et al. 2007; Yoshihara and Sato 2015), species traits dominance (Cornwell et al. 2008; Orwin et al. 2010; Lienin and Kleyer 2012) or divergence (Mokany et al. 2008; Mouillot et al. 2011) have been proved to influence one or several ecosystem functions fundamental to ecosystem services delivery, such as biomass production, decomposition, nutrient cycling or carbon storage.

Ultimately, these ecosystem functions are the foundation of ecosystem services (Costanza et al. 1997; Días et al. 2013) through the integration of direct effects and indirect processes in the food web, which is the third interaction within the proposed framework. They can control the level of delivery of a target ecosystem service (Lange et al. 2015). So far, few papers have dealt with all the components and interactions of the cascading model presented here from management to services (but see Lavorel et al. 2011; Días et al. 2013; Grigulis et al. 2013).

From an operational perspective, it is not crucial to assess all the cascading processes to define the correct management rules aimed at maintaining or increasing a target ecosystem service in a given context. However, the limited understanding of the processes underpinning the response of a target service to management can seriously impede the potential of generalization in other contexts (Wong et al. 2014).

One of the major difficulties in analysing management effects on natural capital, ecosystem functions and services lies in the lack of a common and general typology of management practices. We propose characterizing management practices 
according to the category of inputs used (see for instance, Gregory et al. 2002), which can be represented by gradients along: (1) endogenous or exogenous inputs, which refer respectively to the occurrence or absence of the product added or the action carried out within the pre-intervention ecosystem. For example, planting or seeding native species are endogenous inputs, while planting or seeding non-native species are exogenous inputs; (2) artificial or biological inputs. For instance, using chemical fertilizer corresponds to artificial inputs and mimicking natural disturbance to biological inputs. From this perspective, several situations are possible and are described in Fig. 3.

The regulation of ecosystem functions through modifications of natural capital by management practices can thus change the way ecosystem services are provided and even change the relationships between ecosystem services. Two aspects are fundamental if a certain level of a target ecosystem service is to be achieved. First, a given level of relevant ecosystem functions needs to be attained via management, either directly or indirectly through modification of the manageable properties of natural capital. Second, ecosystem functions should display stability over space and time to ensure the persistence of ecosystem services. Hence, ecosystem resistance and resilience should be integrated as a crucial component when designing management practices (Standish et al. 2014), with resistance as the degree to which a variable is changed following a disturbance (Pimm 1984) and resilience as the ability of an ecosystem to absorb changes of variables and parameters after disturbance (Holling 1973). Depending on the interaction of the pre-intervention ecosystem structure with the management practice, a managed ecosystem will maintain, enhance or decrease the balance between three sets of ecosystem services: (i) primary target ecosystem services (e.g. animal and/or forage production in agriculture), (ii) ecosystem services that support the primary target ecosystem services (e.g. nitrogen fixation or pollination for forage production) and (iii) ecosystem services that were not the aim of the practice (e.g. aesthetic value or flood mitigation). As a consequence, the search for an improved balance in ecosystem services through multifunctional management perspectives and trade-off analyses can be taken into account in the definition of sustainable management practices.

\section{Integrating ecological engineering and ecological intensification into the generic framework}

In this section, we discuss how ecological engineering and ecological intensification can be integrated and more precisely distinguished and unified in our framework. One of the main differences between ecological engineering and ecological intensification is the primary target service: ecological engineering projects are frequently related to land restoration or conservation, in particular for their protection, while ecological intensification focuses on food or vegetation production but increasingly takes into account other ecosystem services (Doré et al. 2011) (Fig. 4). Nevertheless, ecological engineering can also target ecosystem services other than protection and deal with a high diversity of ecosystem services (Brüll et al. 2011). Ecological engineering provides direct inputs that restore altered components of the natural capital, thereby restoring ecosystem functions and services, whereas ecological intensification seeks to optimize some manageable properties
Fig. 3 Different types and gradient of inputs in ecosystem management practices. To illustrate different situations, we placed examples of practices on a plan composed of two axes representing endogenous/ exogenous and artificial/ biological gradients. The four case studies (CS) described in the paper can be found in this plan according to their type and level of inputs: CS1, phytoremediation; CS2, biochar application to agricultural soils; $C S 3$, incorporation of cattle grazing and semi-natural rough pastures to sheep systems; CS4, effect of tree mixture on stand production. The large arrow illustrates a gradient of inputs

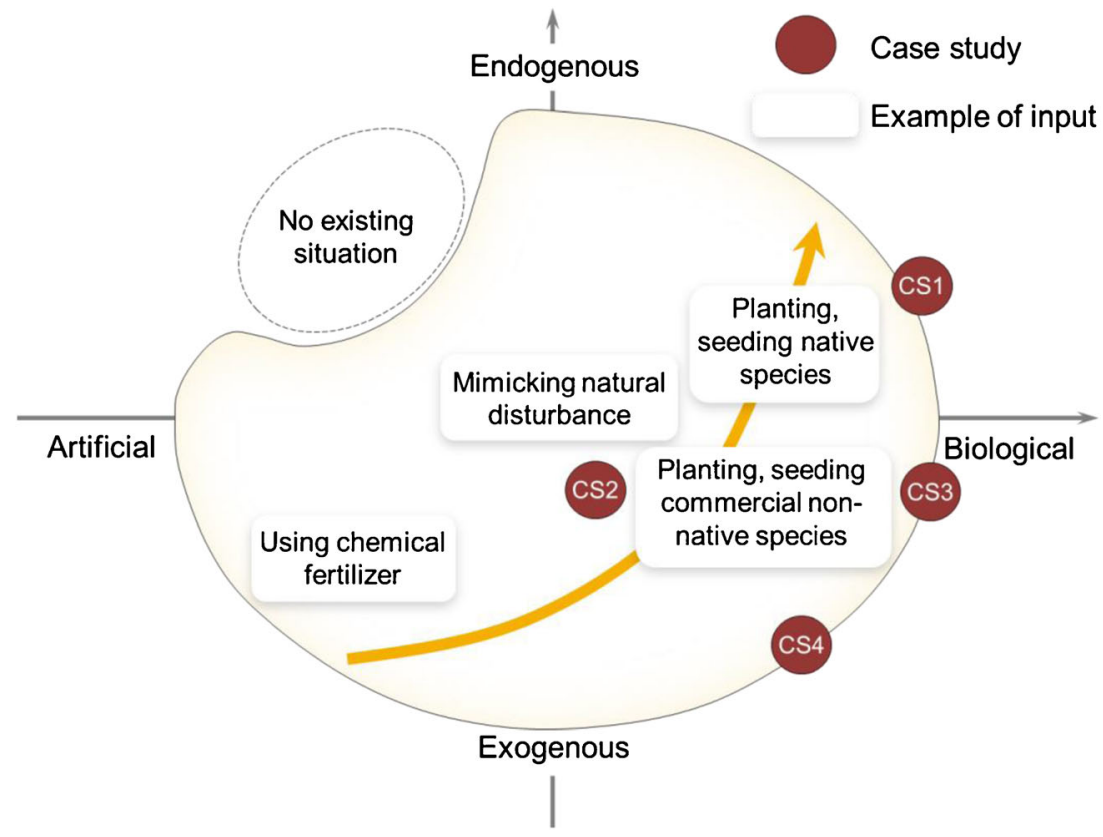


(a) Ecological engineering

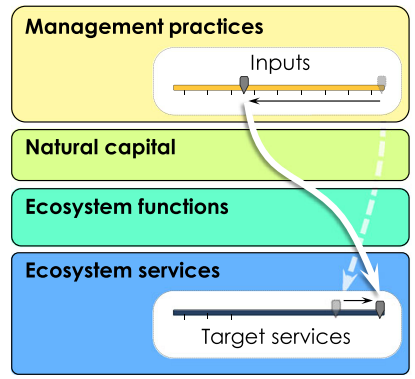

(b) Ecological intensification

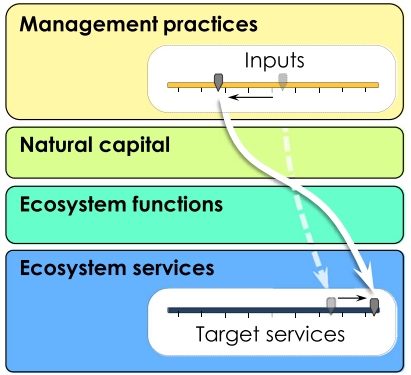

Fig. 4 Representation of ecological engineering (a) and ecological intensification (b) approaches using the generic framework. The dashed transparent arrows represent the cascading effect of a civil engineering (mostly exogenous and artificial inputs) and $\mathbf{b}$ intensive agriculture (mostly biological and exogenous inputs) from management practices to ecosystem services. Ecological engineering and ecological intensification aim to reduce exogenous and artificial inputs while maintaining or improving target services (thin black arrows). Solid white lines represent the cascading effect of a ecological engineering and $\mathbf{b}$ ecological intensification in ecosystem management approaches

of natural capital to enhance ecosystem functions underpinning target ecosystem services such as biomass production.

The relative use over time of artificial or exogenous inputs represents another main difference between ecological engineering and ecological intensification. Considering this can show how the framework might be used to help choose the best approach for a given project such as the following: inciting to use alternative methods compared to classic ones (e.g. bioengineering instead of civil engineering), or determining cost-effectiveness ratios (Fig. 5). Ecological engineering practices can use a large amount of exogenous input in their initial stages; this is related to the high number of projects devoted to ecological restoration where civil engineering is often used. Exogenous and artificial inputs are necessary most of the time for natural site or habitat creation from severely degraded terrains. However, when biodiversity conservation is the main objective of the actions, endogenous and biological inputs are easier to use because actions are aimed more at prevention than restoration. Current considerations in ecological engineering are prone to endogenous inputs. Contrary to civil engineering practices (Fig. 5a), the amount of services provided is likely to increase, sometimes in the long term, almost only based on biological processes in parallel with natural capital development (Fig. 5b). Ecological intensification will reduce the amount of artificial and exogenous inputs with time, despite a larger amount being necessary at the beginning (e.g. planting trees for hedgerow creation). Contrary to intensive agriculture (Fig. 5c), the amount of production in ecological intensification will be increasingly based on biological processes that can promote other services such as organic matter decomposition, pest control by auxiliary species, etc. (Fig. 5d, Bommarco et al. 2013).

Despite these differences between ecological engineering and ecological intensification, management choices are oriented to a well-balanced use of endogenous/exogenous and biological/artificial inputs, with the aim of providing support functions for services that are more efficient, resistant and sustainable over time. Ecological engineering and ecological intensification both try to maximize primary target ecosystem
Fig. 5 Simplified representation of temporal variation of inputs and amount of primary target services for ecological intensification (b) and ecological engineering (d), compared with intensive agriculture (a) and civil engineering (c)

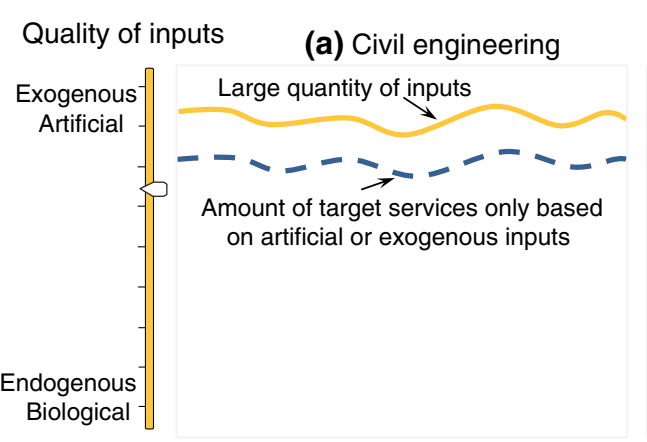

Quality of inputs

(c) Intensive agriculture

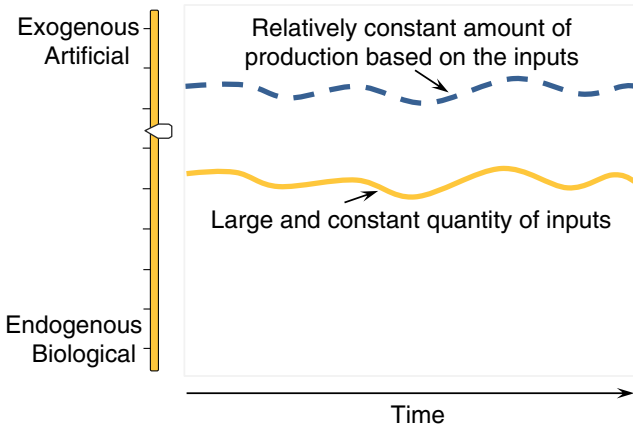

Amount of primary

(b) Ecological engineering target service

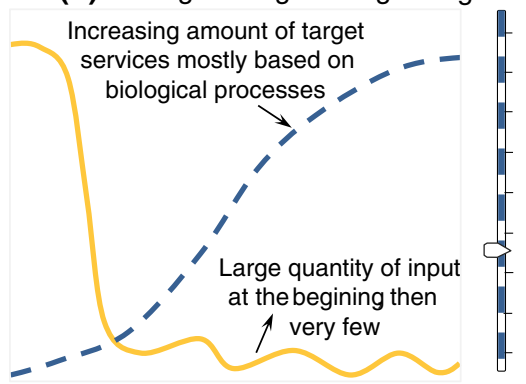

Amount of primary

(d) Ecological intensification target service

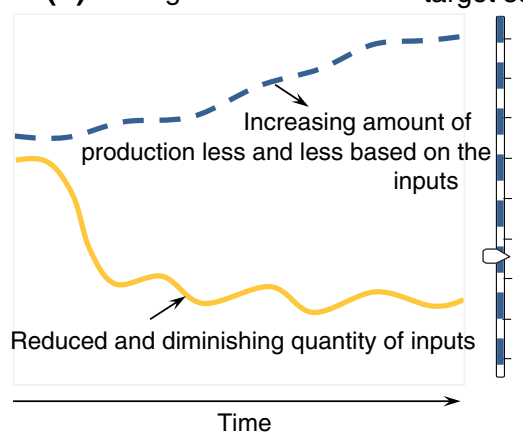


services and to minimize inputs. In this way, the primary target ecosystem service mostly depends on the ecosystem's own properties and functioning, rather than on exogenous inputs. Moreover, one can expect this to result in a more balanced trade-off between other ecosystem services.

\section{Case studies regarding the framework for ecosystem management}

Our proposed framework was applied to four case studies using these two ecosystem management approaches of ecological engineering and ecological intensification (Table 1). These four case studies were chosen from the literature to illustrate the gradient of inputs represented in Fig. 3. For this, we selected recently published case studies of (1) ecological engineering: phytoremediation by Ha et al. (2009) and biochar application to agricultural soils by Smider and Singh (2014); and (2) ecological intensification: incorporating cattle and semi-natural rough grazing to sheep systems by Fraser et al. (2014) and the effect of tree mixture on stand production by Bouillet et al. (2013).

These four examples deal with plant communities. They represent contrasting types of ecosystems (forest, grasslands, crop culture and degraded systems) as well as a wide variety of practices in ecological engineering and ecological intensification according to the gradient of inputs shown in Fig. 3. Input types range from biological and endogenous to artificial and exogenous, sometimes with a mix of various input types. Complex situations exist, for instance regarding biochar, which is both a biological and an artificial input (pyrolysed green waste; Smider and Singh 2014). We identified the natural capital components altered in each case study (e.g. soil components, vegetation composition or plant traits; Table 1) and specified the ecosystem functions that were modified through each modality of ecosystem management. In the four examples, a wide variety of ecosystem services are targeted. However, in three of the four case studies, the main target ecosystem service is related to the function of primary productivity: provisioning services such as the production of food or wood products. Two case studies focus on only one particular ecosystem service: either regulating service (for ecological engineering, waste detoxification; Ha et al. 2009) or provisioning service (for ecological intensification, wood product yield; Bouillet et al. 2013). The two other papers directly refer to a wider variety of ecosystem services: regulating, provisioning and supporting either in a context of ecological engineering (Smider and Singh 2014) or ecological intensification (Fraser et al. 2014). This supports the growing consideration for multi-service assessment through the evaluation of tradeoffs between different ecosystem services.

Overall, despite the differences in terms of the type of ecosystem considered and the ecosystem management approaches/practices applied, these four case studies have successfully been integrated into our generic framework. This framework also illustrates the usefulness of explicitly incorporating natural capital, as an important mediator of ecosystem management approaches. Ultimately, this demonstrates the generic character of the proposed framework that can be applied for a variety of target ecosystem services, as well as for different ecosystem management approaches such as ecological engineering and ecological intensification.

\section{Conclusion}

The framework we propose allows an overview of management practices and ecosystem services by (1) specifying direct and indirect effects between ecosystem functions and ecosystem services, (2) integrating space in time for interactions between ecosystem functions and services, (3) distinguishing manageable and inherent properties in natural capital stocks and (4) specifying the inputs with endogenous/exogenous and biological/artificial gradients.

It should enable identification of differences as well as similarities between various ecosystem management approaches and thus provide opportunities to achieve more generic and operational knowledge on the functioning of managed ecosystems. First, our approach should help researchers to assess the responses of ecosystems depending on the management practices, the efficiency of the latter in providing ecosystem services, as well as the links between ecosystem functions and services. It should also help them quantify potential positive impacts of specific and adapted practices and land uses. For instance, it allowed unification of ecological engineering and ecological intensification by highlighting common processes from management practices to ecosystem services. Finally, the framework will provide practical help to researchers because the identification of individual components for different projects and studies may favour future meta-analyses, cost-benefit analyses and life-cycle analyses and evaluations.

This could help project designers when recommending actions for a specified target. They will be able to quantify more accurately the inputs to be used in a project, ensuring the use of increasingly endogenous and biological inputs. Therefore, practitioners will be able to adapt their prescriptions, with a view to improving sustainability of ecosystems as well as ecosystem services, assuming that changes in land use and practices can increase the quality and the compromises between services.

Finally, this should help managers to recognize the benefits, as well as the costs, of actions of ecological engineering and ecological intensification. Cost-benefit analyses could then allow these actions to be compared with classic analyses, as in civil engineering and intensive agriculture. Benefits can 
Table 1 Integrating four case studies of ecological engineering and ecological intensification into the framework

Ecosystem management approach

Ecological engineering Ecological intensification

\begin{tabular}{|c|c|c|c|c|}
\hline $\begin{array}{l}\text { Case } \\
\text { studies }\end{array}$ & Phytoremediation & $\begin{array}{l}\text { Biochar application to } \\
\text { agricultural soils }\end{array}$ & $\begin{array}{l}\text { Incorporating cattle and semi-natural } \\
\text { rough grazing into sheep systems }\end{array}$ & $\begin{array}{l}\text { Effect of tree mixture on stand } \\
\text { production }\end{array}$ \\
\hline Box 1 & Type of inputs & Type of inputs & Type of inputs & Type of inputs \\
\hline Inputs & $\begin{array}{l}>\text { Semi-endogenous (Eleocharis } \\
\text { acicularis, a species naturally } \\
\text { occurring in the studied area) } \\
>\text { Biological } \\
\text { Level of inputs } \\
>\text { Species was transplanted and } \\
\text { population was increased by } \\
\text { spontaneous new shoot emerging a } \\
\text { few months after transplantation } \\
>\text { Gathering hyperaccumulating } \\
\text { shoots of } E \text {. acicularis }\end{array}$ & $\begin{array}{l}>\text { Exogenous (tomato } \\
\text { green waste from } \\
\text { greenhouse } \\
\text { facilities) } \\
>\text { Biological and } \\
\text { artificial (green } \\
\text { waste converted } \\
\text { into biochar by } \\
\text { pyrolysis) } \\
\text { Level of inputs } \\
>\text { Biochar production } \\
\text { and amendment (5- } \\
15 \text { g.k }{ }^{-1} \text { ) } \\
>\text { Reduction in } \\
\text { fertilizer production } \\
\text { and amendment } \\
\text { (50-100 \%) }\end{array}$ & $\begin{array}{l}>\text { Exogenous (introducing cattle } \\
\text { grazing = mixed grazing systems) } \\
\text { and semi-endogenous (local semi- } \\
\text { natural rough grasslands) } \\
>\text { Biological (cattle; rough } \\
\text { grasslands) } \\
\text { Level of inputs } \\
>\text { Modern crossbred cattle grazing at } \\
\text { a ratio of } 6: 1 \text { or } 12: 1 \text {, traditional } \\
\text { cattle breed at a ratio of } 6: 1 \\
>4 \text {-ha plots of semi-natural rough } \\
\text { grasslands for cattle grazing }\end{array}$ & $\begin{array}{l}>\text { Exogenous (Acacia) } \\
>\text { Biological } \\
\text { Level of inputs } \\
>\text { Plantation of Acacia (A) in } \\
\text { Eucalyptus (E) stands (various } \\
\text { ratios 25A:100E, 50A:100E, } \\
\text { 100A:100E, 50A:50E) } \\
>\text { Reduction in N-fertilization } \\
\quad \text { production and amendment } \\
\quad \text { (except at planting) }\end{array}$ \\
\hline $\begin{array}{l}\text { Box } 2 \\
\text { Natural } \\
\quad \text { capital }\end{array}$ & $\begin{array}{l}>\text { Vegetation: spontaneously } \\
\text { occurring vegetation and } \\
\text { transplanted } E \text {. acicularis } \\
\rightarrow \text { Accumulation of } \mathrm{Fe}, \mathrm{Cu} \text { and } \mathrm{Zn} \\
\quad \text { in E. acicularis shoots }\end{array}$ & $\begin{array}{l}>\text { Vegetation: } \\
\text { monoculture of } \\
\text { Hybrid sweet corn } \\
\rightarrow \text { Modification of } \\
\text { shoot dry matter } \\
>\text { Two different soil } \\
\text { types: Tenosol and } \\
\text { Ferrosol } \\
\rightarrow \text { Modification of } \\
\text { soil properties }\end{array}$ & $\begin{array}{l}>\text { Herbivore: foraging behaviour and } \\
\text { physiology } \\
\rightarrow \text { Modification of pasture use } \\
\text { efficiency } \\
>\text { Vegetation: floristic and structural } \\
\text { diversity } \\
\rightarrow \text { Modification of available } \\
\text { habitats through use of rough } \\
\text { grasslands }\end{array}$ & $\begin{array}{l}>\text { Vegetation: plantations of } \\
\text { eucalyptus and acacia } \\
\rightarrow \text { Modification of tree growth } \\
\text { (height, circumference and } \\
\text { stand stemwood biomass) } \\
>\text { Five sites in Congo and Brazil } \\
\text { with two different soil types: } \\
\text { Ferralsols and Ferralic } \\
\text { arenosols }\end{array}$ \\
\hline $\begin{array}{l}\text { Box } 3 \\
\text { Ecosystem } \\
\text { func- } \\
\text { tions }\end{array}$ & $\begin{array}{l}>\text { Modification of trace elements } \\
\text { uptake mostly in the roots }(\mathrm{Cr}, \mathrm{Mn} \\
\text { and } \mathrm{Ni} \text { ) or mostly in the shoots }(\mathrm{Fe}, \\
\mathrm{Cu} \text { and } \mathrm{Zn}) \text {. } \\
\rightarrow \text { Once shoots are gathered, } \mathrm{Fe}, \mathrm{Cu} \\
\text { and } \mathrm{Zn} \text { ecosystem concentration is } \\
\text { reduced }\end{array}$ & $\begin{array}{l}>\text { Modification of net } \\
\text { primary } \\
\text { productivity } \\
\rightarrow+(\text { Ferrosol), }- \\
\text { (Tenosol) } \\
>\text { Modification of } \\
\text { nutrient cycling in } \\
\text { plant and soil } \\
\rightarrow \text { Nutrient uptake } \\
\text { by plants is soil type } \\
\text { dependent }\end{array}$ & $\begin{array}{l}>\text { Modification of the efficiency of } \\
\text { primary production towards animal } \\
\text { performance } \\
\rightarrow \text { Enhanced livestock productivity } \\
\text { in mixed grazing systems } \\
>\text { Modification of nitrogen cycle } \\
\rightarrow \text { Reduced methane emission in } \\
\text { mixed grazing systems } \\
>\text { Modification of the habitat function } \\
\text { of grasslands } \\
\rightarrow \text { Suitable habitats for birds and } \\
\text { butterflies }\end{array}$ & $\begin{array}{l}>\text { Modification of net primary } \\
\text { productivity } \\
\rightarrow \text { Depends on A/E ratio, } \\
\text { climate and soil type }\end{array}$ \\
\hline $\begin{array}{l}\text { Box } 4 \\
\text { Ecosystem } \\
\text { services }\end{array}$ & $\begin{array}{l}>\text { Regulating: waste detoxification } \\
\text { (phytoremediation of mine tailing } \\
\text { and drainage rich in trace elements) }\end{array}$ & $\begin{array}{l}>\text { Supporting: nutrient } \\
\text { cycling, soil } \\
\text { formation \& } \\
\text { primary production } \\
\rightarrow+(\text { Ferrosol), }- \\
\text { (Tenosol) } \\
>\text { Provisioning: food } \\
\rightarrow+\text { (Ferrosol), }- \\
\text { (Tenosol) } \\
>\text { Regulating: climate } \\
\rightarrow+\text { Soil C storage }\end{array}$ & $\begin{array}{l}>\text { Supporting: biodiversity, } \\
\text { pollination } \\
\rightarrow+\text { (Enhanced biodiversity of } \\
\text { birds and butterflies) } \\
>\text { Provisioning: food (milk, meat) } \\
\rightarrow+\text { Improved in mixed grazing } \\
\text { systems } \\
>\text { Regulating: climate } \\
\rightarrow-\text { Reduced greenhouse gas } \\
\text { emissions in mixed grazing } \\
\text { systems }\end{array}$ & $\begin{array}{l}>\text { Provisioning: wood products } \\
\rightarrow+(\text { Warm humid tropical } \\
\text { climate and Ferralic arenosol }= \\
\text { Congo site })\end{array}$ \\
\hline Reference & Ha et al. (2009) & $\begin{array}{l}\text { Smider and Singh } \\
(2014)\end{array}$ & Fraser et al. (2014) & Bouillet et al. (2013) \\
\hline
\end{tabular}


be economic but also social or ecological. This would be the case, for instance, in terms of land being attractive to people. For example, a remediation action seeking to clean polluted soils will have an advantage if it is considered to be an action of ecological restoration. Managers should also be able to quantify more accurately the expected services in their ecological, social and economic dimensions. It should be easier for managers to define the objectives of an ecological engineering or ecological intensification project and to impose constraints for the use of inputs.

All this promotes the development of methods to assess the efficiency of ecological engineering and ecological intensification projects. The benefits could therefore be better evaluated in their ecological purposes (biodiversity in particular), as well as in the nature and the significance of the endogenous and biological inputs used.

Acknowledgments We would like to thank Sophie Labonne for her contribution on the manuscript, as well as two anonymous reviewers for their helpful comments. This work was partially supported by the FORGECO project (ANR-09-STRA-02-01) and the MOUVE project (ANR-10-STRA-0005). Irstea Grenoble is part of Labex OSUG@2020 (ANR10 LABX56).

\section{References}

Andrey A, Humbert JY, Pernollet C, Arlettaz R (2014) Experimental evidence for the immediate impact of fertilization and irrigation upon the plant and invertebrate communities of mountain grasslands. Ecol Evol 4:2610-2623. doi:10.1002/ece3.1118

Balvanera P, Pfisterer AB, Buchmann N, He JS, Nakashizuka T, Raffaelli D, Schmid B (2006) Quantifying the evidence for biodiversity effects on ecosystem functioning and services. Ecol Lett 9:1146-1156. doi:10.1111/j.1461-0248.2006.00963.x

Barot S, Lata JC, Lacroix G (2012) Meeting the relational challenge of ecological engineering within ecological sciences. Ecol Eng 45:1323. doi:10.1016/j.ecoleng.2011.04.006

Bennett EM, Peterson GD, Gordon LJ (2009) Understanding relationships among multiple ecosystem services. Ecol Lett 12:13941404. doi:10.1111/j.1461-0248.2009.01387.x

Bommarco R, Kleijn D, Potts SG (2013) Ecological intensification: harnessing ecosystem services for food security. Trends Ecol Evol 28:230-238. doi:10.1016/j.tree.2012.10.012

Bouillet JP, Laclau JP, De Moraes Gonçalves JL et al (2013) Eucalyptus and Acacia tree growth over entire rotation in single- and mixedspecies plantations across five sites in Brazil and Congo. For Ecol Manag 301:89-101. doi:10.1016/j.foreco.2012.09.019

Briner S, Huber R, Bebi P, Elkin C, Schmatz DR, Grêt-Regame A (2013) Trade-offs between ecosystem services in a mountain region. Ecol Soc 18:35. doi:10.5751/ES-05576-180335

Brüll A, van Bohemen H, Costanza R, Mitsch WJ (2011) Benefits of ecological engineering practices. Procedia Environ Sci 9:16-20. doi:10.1016/j.proenv.2011.11.004

Cassman KG (1999) Ecological intensification of cereal production systems: yield potential, soil quality, and precision agriculture. Proc Natl Acad Sci U S A 96:5952-5959. doi:10.1073/pnas.96.11.5952

Cavender-Bares JP, Balvanera EK, Polasky S (2015) Ecosystem service trade-offs across global contexts and scales. Ecol Soc 20:22
Cornwell WK, Cornelissen JHC, Amatangelo K et al (2008) Plant species traits are the predominant control on litter decomposition rates within biomes worldwide. Ecol Lett 11:1065-1071. doi:10.1111/j.14610248.2008.01219.x

Costanza R, Daly HE (1992) Natural capital and sustainable development. Conserv Biol 6:37-46. doi:10.1046/j.1523-1739.1992. 610037.x

Costanza R, d'Arge R, de Groot R et al (1997) The value of the world's ecosystem services and natural capital. Nature 387:253-260. doi:10. 1038/387253a0

de Groot RS, Alkemade R, Braat L, Hein L, Willemen L (2010) Challenges in integrating the concept of ecosystem services and values in landscape planning, management and decision making. Ecol Complex 7:260-272. doi:10.1016/j.ecocom.2009.10.006

Deléglise C, Loucougaray G, Alard D (2011) Spatial patterns of species and plant traits in response to 20 years of grazing exclusion in subalpine grassland communities. J Veg Sci 22:402-413. doi:10.1111/j. 1654-1103.2011.01277.x

Días ATC, Berg MP, De Bello F, Van Oosten AR, Bila K, Moretti M (2013) An experimental framework to identify community functional components driving ecosystem processes and services delivery. $\mathrm{J}$ Ecol 101:29-37. doi:10.1111/1365-2745.12024

Dominati E, Patterson M, Mackay A (2010) A framework for classifying and quantifying the natural capital and ecosystem services of soils. Ecol Econ 69:1858-1868. doi:10.1016/j.ecolecon.2010.05.002

Doré T, Makowski D, Malézieux E, Munier-Jolain N, Tchatmitchian M, Tittonell P (2011) Facing up to the paradigm of ecological intensification in agronomy: revisiting methods, concepts and knowledge. Eur J Agron 34:197-210. doi:10.1016/j.eja.2011.02.006

Duncker PS, Rauland-Rasmussen K, Gundersen P et al (2012) How forest management affects ecosystem services, including timber production and economic return: synergies and trade-offs. Ecol Soc 17(4):50. doi:10.5751/ES-05066-170450

Duru M, Cruz P, Ansquer P, Navas ML (2014) Standing herbage mass: an integrated indicator of management practices for examining how fertility and defoliation regime shape the functional structure of species-rich grasslands. Ecol Indic 36:152-159. doi:10.1016/j. ecolind.2013.07.015

Fraser MD, Moorby JM, Vale JE, Evans DM (2014) Mixed grazing systems benefit both upland biodiversity and livestock production. PloS One 9:e89054. doi:10.1371/journal.pone.0089054

Fridley JD (2002) Resource availability dominates and alters the relationship between species diversity and ecosystem productivity in experimental plant communities. Oecologia 132:271-277. doi:10.1007/ s00442-002-0965-x

Gosselin F (2008) Redefining ecological engineering to promote its integration with sustainable development and tighten its links with the whole of ecology. Ecol Eng 32:199-205. doi:10.1016/j.ecoleng. 2007.11.007

Gregory PJ, Ingram JSI (2000) Global change and food and forest production: future scientific challenges. Agric Ecosyst Environ 82:3-14

Gregory PJ, Ingram JSI, Andersson R et al (2002) Environmental consequences of alternative practices for intensifying crop production. Agric Ecosyst Environ 88:279-290

Griffon M (2013) Qu'est-ce que l'agriculture écologiquement intensive? Quae, Versailles

Grigulis K, Lavorel S, Krainer U, Legay N, Baxendale C, Dumont M, Kastl E, Arnoldi C, Bardgett RD, Poly F, Pommier T, Schloter M, Tappeiner U, Bahn M, Clément JC (2013) Relative contributions of plant traits and soil microbial properties to mountain grassland ecosystem services. J Ecol 101:47-57. doi:10.1111/ 1365-2745.12014

Guo LB, Gifford RM (2002) Soil carbon stocks and land use change: a meta-analysis. Glob Chang Biol 8:345-360. doi:10.1046/j.13541013.2002.00486.x 
Ha NTH, Sakakibara M, Sano S, Hori RS, Sera K (2009) The potential of Eleocharis acicularis for phytoremediation: case study at an abandoned mine site. Clean Soil Air Water 37:203-208

Holling CS (1973) Resilience and stability of ecological systems. Annu Rev Ecol Evol Syst 4:1-23

Hungate BA, Hart SC, Selmants PC, Boyle SI, Gehring CA (2007) Soil responses to management, increased precipitation, and added nitrogen in ponderosa pine forests. Ecol Appl 17:1352-1365

Jandl R, Lindner M, Vesterdal L, Bauwens B, Baritz R, Hagedorn F, Johnson DW, Minkkinen K, Byrne KA (2007) How strongly can forest management influence soil carbon sequestration? Geoderma 137:253-268. doi:10.1016/j.geoderma.2006.09.003

Kirwan L, Luescher A et al (2007) Evenness drives consistent diversity effects in an intensive grassland system across European sites. J Ecol 95:530-539. doi:10.1111/j.1365-2745.2007.01225.x

Köhl L, Oehl F, Van Der Heijden MGA (2014) Agricultural practices indirectly influence plant productivity and ecosystem services through effects on soil biota. Ecol Appl 24:1842-1853

Kremen C, Miles A (2012) Ecosystem services in biologically diversified versus conventional farming systems: benefits, externalities, and trade-offs. Ecol Soc 17:40. doi:10.5751/ES-05035-170440

Lafond V, Cordonnier T, Courbaud B (2015) Reconciling biodiversity conservation and timber production in mixed uneven-aged mountain forests: identification of ecological intensification pathways. Environ Manag (in press)

Lagomarsino A, Grego S, Marhan S, Moscatelli MC, Kandeler E (2009) Soil management modifies micro-scale abundance and function of soil microorganisms in a Mediterranean ecosystem. Eur J Soil Sci 60:2-12. doi:10.1111/j.1365-2389.2008.01113.x

Laliberté E, Tylianakis JM (2012) Cascading effects of long-term landuse changes on plant traits and ecosystem functioning. Ecology 93: 145-155. doi:10.1890/11-0338.1

Lange M, Eisenhauer N, Sierra C, Bessler H, Engels C et al (2015) Plant diversity increases soil microbial activity and soil carbon storage. Nat Commun 6:6707. doi:10.1038/ncomms 7707

Lata JC, Barot S, Lacroix G (2011) Ecological engineering: from concepts to applications: foreword. Procedia Environ Sci 9:1-5. doi:10. 1016/j.proenv.2011.11.001

Lavorel S, Grigulis K, Lamarque P, Colace MP, Garden D, Girel J, Pellet G, Douzet R (2011) Using plant functional traits to understand the landscape distribution of multiple ecosystem services. J Ecol 99: 135-147. doi:10.1111/j.1365-2745.2010.01753.x

Lienin P, Kleyer M (2012) Plant trait responses to the environment and effects on multiple ecosystem properties. Basic Appl Ecol 13:301311. doi:10.1016/j.baae.2012.05.002

Malcolm BJ, Cameron KC, Di HJ, Edwards GR, Moir JL (2014) The effect of four different pasture species compositions on nitrate leaching losses under high $\mathrm{N}$ loading. Soil Use Manag 30:58-68. doi:10.1111/sum. 12101

Mitsch WJ (2012) What is ecological engineering? Ecol Eng 4(5):5-12. doi:10.1016/j.ecoleng.2012.04.013

Mitsch WJ, Jørgensen SE (1989) Ecological engineering: an introduction to ecotechnology. Wiley, New York

Mitsch WJ, Jørgensen SE (2004) Ecological engineering and ecosystem restoration. Wiley, New York

Mokany K, Ash J, Roxburgh S (2008) Functional identity is more important than diversity in influencing ecosystem processes in a temperate native grassland. J Ecol 96:884-893. doi:10.1111/j.1365-2745. 2008.01395.x

Molina P, Patricio Ojeda F, Aldana M, Pulgar VM, Garcia-Huidobro MR, Pulgar J (2014) Spatial and temporal variability in subtidal macroinvertebrates diversity patterns in a management and exploitation area for benthic resources (MEABRs). Ocean Coast Manag 93: $121-128$

Morris SJ, Boerner REJ (1998) Interactive influences of silvicultural management and soil chemistry upon soil microbial abundance and nitrogen mineralization. For Ecol Manag 103:129-139. doi: 10.1016/S0378-1127(97)00183-7

Mouillot D, Villéger S, Scherer-Lorenzen M, Mason NWH (2011) Functional structure of biological communities predicts ecosystem multifunctionality. PLoS ONE 6, e17476. doi:10.1371/journal.pone. 0017476

Nyfeler D, Huguenin-Elie O, Suter M, Frossard E, Luscher A (2011) Grass-legume mixtures can yield more nitrogen than legume pure stands due to mutual stimulation of nitrogen uptake from symbiotic and non-symbiotic sources? Agric Ecosyst Environ 140:155-163. doi:10.1016/j.agee.2010.11.022

Orwin KH, Buckland SM, Johnson D, Turner BL, Smart S, Oakley S, Bardgett RD (2010) Linkages of plant traits to soil properties and the functioning of temperate grassland. J Ecol 98:1074-1083. doi:10. $1111 / j .1365-2745.2010 .01679 . x$

Parfitt RL, Yeates GW, Ross DJ, Schon NL, Mackay AD, Wardle DA (2010) Effect of fertilizer, herbicide and grazing management of pastures on plant and soil communities. Appl Soil Ecol 45:175186. doi:10.1016/j.apsoil.2010.03.010

Pimm SL (1984) The complexity and stability of ecosystems. Nature 307: $321-326$

Potschin MB, Haines-Young RH (2011) Ecosystem services: exploring a geographical perspective. Prog Phys Geogr 35:575-594. doi:10. $1177 / 0309133311423172$

Pretty J (2008) Agricultural sustainability: concepts, principles and evidence. Philos Trans R Soc Lond B Biol Sci 363(1491):447-465. doi:10.1098/rstb.2007.2163

Quétier F, Thébault A, Lavorel S (2007) Plant traits in a state and transition framework as markers of ecosystem response to land-use change. Ecol Monogr 77:33-52. doi:10.1890/06-0054

Rey F, Burylo M (2014) Can bioengineering structures made of willow cuttings trap sediment in eroded marly gullies in a Mediterranean mountainous climate? Geomorphology 204:564-572. doi:10.1016/ j.geomorph.2013.09.003

Rey F, Gosselin F, Doré A (eds) (2014) Ingénierie écologique : action par et/ou pour le vivant? Quae, Versailles

Rossignol N, Bonis A, Bouzillé JB (2006) Consequence of grazing pattern and vegetation structure on the spatial variations of net $\mathrm{N}$ mineralization in a wet grassland. Appl Soil Ecol 31:62-72

Schwartz MW, Brigham CA, Hoeksema JD, Lyons KG, Mills MH, van Mantgem PJ (2000) Linking biodiversity to ecosystem function: Implications for conservation ecology. Oecologia 122:297-305. doi:10.1007/s004420050035

Schwenk WS, Donovan TM, Keeton WS, Nunery JS (2012) Carbon storage, timber production, and biodiversity: comparing ecosystem services with multi-criteria decision analysis. Ecol Appl 22:16121627

Sebastia MT, Palero N, de Bello F (2011) Changes in management modify agro-diversity in sainfoin swards in the Eastern Pyrenees. Agron Sustain Dev 31:533-540. doi:10.1007/s13593-011-0008-2

Serrano J, Marques da Silva J, Shahidian S (2014) Spatial and temporal patterns of potassium on grazed permanent pastures - management challenges. Agric Ecosyst Environ 188:29-39. doi:10.1016/j.agee. 2014.02.012

Smider B, Singh B (2014) Agronomic performance of a high ash biochar in two contrasting soils. Agric Ecosyst Environ 191:99-107. doi:10. 1016/j.agee.2014.01.024

Snapp SS, Gentry LE, Harwood R (2010) Management intensity—not biodiversity - the driver of ecosystem services in a long-term row crop experiment. Agric Ecosyst Environ 138:242-248

Standish RJ, Hobbs RJ, Mayfield MM et al (2014) Resilience in ecology: abstraction, distraction, or where the action is? Biol Conserv 177: $43-51$

Stokes A, Barot S, Lata JC, Lacroix G, Jones CG, Mitsch WJ (2012) Ecological engineering: from concepts to applications. Ecol Eng 45:1-4. doi:10.1016/j.ecoleng.2012.04.035 
Stokes A, Douglas G, Fourcaud T et al (2014) Ecological mitigation of hillslope instability: ten key issues facing practitioners and researchers. Plant Soil 377:1-23. doi:10.1007/s11104-014-2044-6

Suchkova N, Tsiripidis I, Alifragkis D, Ganoulis J, Darakas E, Sawidis T (2014) Assessment of phytoremediation potential of native plants during the reclamation of an area affected by sewage sludge. Ecol Eng 69:160-169. doi:10.1016/j.ecoleng.2014.03.029

Teague WR, Dowhower SL, Baker SA, Haile N, DeLaune PB, Conover DM (2011) Grazing management impacts on vegetation, soil biota and soil chemical, physical and hydrological properties in tall grass prairie. Agric Ecosyst Environ 141:310-322. doi:10.1016/j.agee. 2011.03.009

Tixier P, Duyck PF, Côte F, Caron-Lormier G, Malézieux E (2013) Food web-based simulation for agroecology. Agron Sustain Dev 33:663670. doi:10.1007/s13593-013-0139-8

Valentine J, Clifton-Brown J, Hastings A, Robson P, Allison G, Smith P (2012) Foods vs. fuel: the use of land for lignocellulosic 'next generation' energy crops that minimize competition with primary food production. GCB Bioenergy 4:1-19. doi:10.1111/j.1757-1707.2011. 01111.x
Van Meerbeek K, Helsen K, Hermy M (2014) Impact of land-use intensity on the conservation of functional and phylogenetic diversity in temperate semi-natural plant communities. Biodivers Conserv 23: 2259-2272

Wagg C, Bendera SF, Widmerc F, van der Heijdena MGA (2014) Soil biodiversity and soil community composition determine ecosystem multifunctionality. PNAS 111:5266-5270. doi:10.1073/pnas. 1320054111

Wallace KJ (2007) Classification of ecosystem services: problems and solutions. Biol Conserv 139:235-246

Wickings K, Grandy AS (2013) Management intensity interacts with litter chemistry and climate to drive temporal patterns in arthropod communities during decomposition. Pedobiologia 56:105112

Wong CP, Jiang B, Kinzig AP, Lee KN, Ouyang Z (2014) Linking ecosystem characteristics to final ecosystem services for public policy. Ecol Lett 18:108-118. doi:10.1111/ele.12389

Yoshihara Y, Sato S (2015) The relationship between dung beetle species richness and ecosystem functioning. Appl Soil Ecol 88:21-25. doi: 10.1016/j.apsoil.2014.12.001 